\title{
LATE VENDIAN AERIAL ALKALINE VOLCANISM IN WINTER COAST KIMBERLITE AREA (ARKHANGELSK DIAMONDIFEROUS PROVINCE)
}

\author{
V.S.Shchukin ${ }^{1}$, S.M.Sablukov ${ }^{2}$, L.I.Sablukova ${ }^{2}$, E.A.Belousova ${ }^{3}$, V.L.Griffin ${ }^{3}$ \\ ${ }^{1}$ JSC Arkhangelsk Diamonds, Russia; ${ }^{2}$ Central Research Institute of Geological Prospecting (TsNIGRI), Russia; \\ ${ }^{3}$ ARC National Key Center GEMOC, Australia
}

\section{INTRODUCTION}

The Winter Coast kimberlite area is located in the zone of intensive Riphean rift-forming within the Kola-Dvina paleorift system $[2,3]$ that has become active again in Early Hercynian. The fact is proved by presence of unique diversity of Late Devonian rocks composed of basic and ultrabasic volcanites including commercial diamondiferous kimberlites[1]. This makes it possible to assume specific magmatic activity of rift structures in earlier time, in Late Proterozoic.

In February 2000, JSC "Arkhangelsk Diamonds" performed works in the western part of the Winter Coast kimberlite area and in course of check drilling of local magnetic anomalies numerous volcanic shows were found in Vendian terrigenous rocks. They were of the type that was new for the northern Russian Platform and included Late Vendian lavas and tuffs of potassic calc-alkali lamprophyres close to minette. They were discovered in anomalies forming a chain of the northeastern trend and about $70 \mathrm{~km}$ length located parallel to the White Sea Entrance (Figure).

\section{GEOLOGICAL STRUCTURE OF VOLCANIC COMPLEXES}

Volcanic bodies of the new type were discovered as interbeds in Upper Vendian terrigenous rocks of Mezen sequence of Kotlin Regional Stage represented by alternating horizontal thin parallel bedded greenish-gray and reddish-brown mudstones and siltstones with subordinated fine-grained sandstones of the same color. As a rule, every anomaly comprises actually all main structural and genetic types of volcanic rocks located at different levels of the same section: effusive rocks (lavas, in less extent lava breccia), magmaclasts and sedimentary/magmaclastic rocks (tuffs and tuffites), volcanic sedimentary rocks (tuff aleurolites and tuff mudstones). Effusive volcanic rocks form subhorisontal sheets and streams (1-4 interbeds per well section) of 1 $\mathrm{cm}$ to $18 \mathrm{~cm}$ thickness occurring in conformity with terrigenous Vendian rocks. Occasionally, lavas form intersecting subvertical, branching, splitted inclusions (veins) of irregular shape and of 1-12 mm thickness. Tuffs and tuffites also occur as subhorizontal sheets of $0.5-5 \mathrm{~cm}$ thickness. Volcanic rocks alternate with Vendian sedimentary terrigenous rocks forming compound units of eruptive rocks; their thickness is 0.5 $\mathrm{m}$ to $4 \mathrm{~m}$. Incomplete lateral extension of volcanic

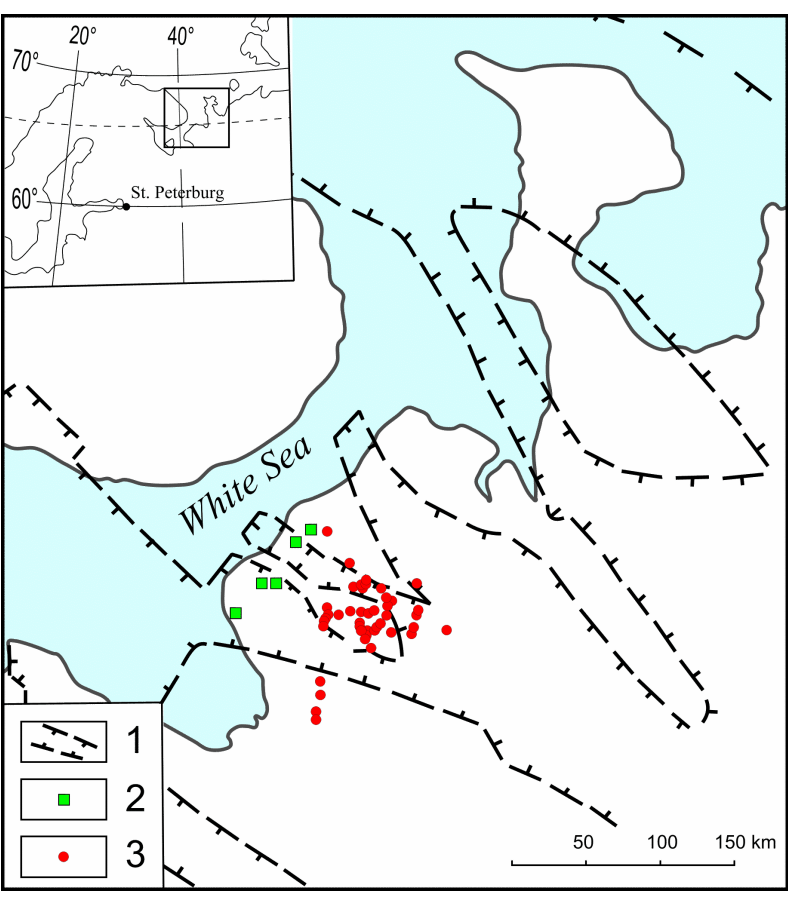

Figure: Structure Sheme of the Kola-Dvina paleorift system [3] and location of Late Vendian lamprophyre volcanic rocks and Late Devonian basic and ultrabasic volcanites.

1. Riphean paleorift system.

2. Late Vendian lamprophyre volcanic rocks.

3. Late Devonian basic and ultrabasic volcanites (Kimberlites, picrites, melilithites and basalts).

complexes proven by drilling is over $150 \mathrm{~m}$; at the same time, volcanic rocks are of local extension - they pinch out quite quickly and likely represent products of subaqueous or aerial eruptions of small-size amounts of volcanic matter through fractures.

\section{PETROGRAPHICAL COMPOSITION OF VOLCANIC ROCKS}

Macroscopically, discovered volcanic rocks are poorly consolidated, soft, wax-like, schistose deposits of brownish-gray color, tinged with violet and pink (lavas) or of greenish-gray and bluish-gray color (tuffs and tuffites), of heterogeneous small-spotted and indistinctly banded coloring. Schistosity is of subhorizontal trend. According to x-diffractometry data, rocks are almost completely shaly; kaolinite and hematite (sometimes goethite) dominate; illite, chlorite, and ordered hydromica/ montmorillonite occur in less amounts. 
Despite of very high alteration, specific features of volcanic rocks have preserved sufficiently enough; their original mineral composition can be reliably reconstructed. The rocks are characterized by stable paragenesis of original minerals: biotite \pm changed glass \pm apatite \pm zircon \pm feldspathoids \pm ores in deposits of lava habit (in tuffs glass is replaced by basal cement formed as a result of fine-ashy material destruction).

Rocks of lava habit (effusive rocks) are characterized by relict porphyric structure caused by development of idiomorphic and subidiomorphic biotite phenocrysts (packets) changed in various extent and submerged in apovitreous matrix of plicated and fluidal texture, sometimes with traces of amygdaloidal texture. In general, the rock texture is massive, sometimes fluidal, breccia-like texture of lava breccias also occurs. Crystallization of lavas is very insignificant, rocks of aphyric and spodarophyric structure dominate; in fact,
Biotite is represented mainly by hexagonal tabular crystals, less amount of crystals (in tuffs) is represented by flakes of irregular shape. Biotite grains are typically of $0,05-0,2 \mathrm{~mm}$ size, occasionally up to $0.8 \mathrm{~mm}$ size, often aggregates of 2-5 grains with total size of 0,5-1,00 $\mathrm{mm}$ (up to $1.5 \mathrm{~mm}$ ) occur. Biotite is of dark greenishbrown to black color, with large crystals. Biotite is mainly fresh, often altered by thin plates of white silica and chlorite along jointing, sometimes up to formation of complete chlorite-quartzine pseudomorphs with typical network structure of alteration. Mica grains are of rather homogeneous composition and of the same type as for lava phenocrysts and tuff crystoclasts; they are characterized by stable high content of $\mathrm{TiO}_{2}(4,64-$ $6,33 \%)$ and $\mathrm{Al}_{2} \mathrm{O}_{3}(12,65-17,42 \%)$, lack of $\mathrm{Cr}_{2} \mathrm{O}_{3}(0,00-$ $0,07 \%)$ with unstable but high content of $\mathrm{FeO}(15,35$ $27,88 \%)$ and low content $\mathrm{MgO}(5,75-13,28 \%)$ that make it possible to define them as Ti-biotite (tabl. 1). The studied grain compositions shown on Mitchell's

\section{T able 1: Compositions of bidite phenoc ysts and a ystod costs fr am lampr ophyr es of the Winter Coost}

\begin{tabular}{|c|c|c|c|c|c|c|c|c|c|c|c|c|c|}
\hline 1 & Samde\# & Rook & $\mathrm{SiO} 2$ & $\mathrm{TiO} 2$ & $\mathrm{Al} 2 \mathrm{O3}$ & ar203 & $\mathrm{FeO}$ & $\mathrm{MnO}$ & MgO & $\mathrm{COO}$ & $\mathrm{No} O \mathrm{O}$ & $\mathrm{K} 2 \mathrm{O}$ & T otd \\
\hline 1 & LT -32/3-66.5-6/1 & lava & 33,07 & 5,31 & 12,82 & 0,00 & 29,60 & 0,22 & 4,31 & 0,00 & 0,37 & 8,86 & 94,56 \\
\hline 2 & & & 33,47 & 5,22 & 13,05 & 0,00 & 29,31 & 0,25 & 4,55 & 0,00 & 0,37 & 8,71 & 94,93 \\
\hline 3 & ZC-14/2-50 & Iava & 37,54 & 5,86 & 13,97 & 0,00 & 19,43 & 0,14 & 12,27 & 0,02 & 0,55 & 9,82 & 99,60 \\
\hline 4 & & & 38,16 & 6,33 & 13,48 & 0,03 & 19,88 & 0,16 & 12,44 & 0,00 & 0,66 & 9,74 & 100,88 \\
\hline 5 & ZC-14/3-51.8 & lava & 36,69 & 5,71 & 13,52 & 0,01 & 19,68 & 0,20 & 13,28 & 0,02 & 0,70 & 9,41 & 99,22 \\
\hline 6 & & (vein) & 37,02 & 5,65 & 13,17 & 0,00 & 19,42 & 0,13 & 12,28 & 0,00 & 0,57 & 9,33 & 97,57 \\
\hline 7 & & & 36,93 & 5,32 & 13,12 & 0,00 & 23,32 & 0,25 & 9,76 & 0,00 & 0,49 & 9,56 & 98,75 \\
\hline 8 & ZC-14/5-86.4-3-2 & 2 tuff & 35,51 & 5,48 & 14,13 & 0,00 & 24,96 & 0,28 & 5,99 & 0,00 & 0,54 & 7,84 & 94,73 \\
\hline 9 & & & 35,30 & 6,17 & 12,65 & 0,00 & 26,60 & 0,23 & 6,83 & 0,00 & 0,71 & 8,97 & 97,46 \\
\hline 10 & & & 36,97 & 5,17 & 15,96 & 0,07 & 24,95 & 0,08 & 5,75 & 0,02 & 0,34 & 7,78 & 97,09 \\
\hline 11 & & & 35,31 & 4,85 & 13,85 & 0,00 & 24,35 & 0,24 & 6,37 & 0,00 & 0,54 & 7,90 & 93,41 \\
\hline 12 & ZC-14/6-95.6 & tuff & 38,28 & 4,64 & 17,42 & 0,02 & 15,32 & 0,05 & 9,67 & 0,00 & 0,60 & 7,50 & 93,50 \\
\hline 13 & & & 36,99 & 5,41 & 13,36 & 0,00 & 19,76 & 0,12 & 11,40 & 0,00 & 0,59 & 9,60 & 97,23 \\
\hline 14 & & & 35,72 & 5,91 & 13,80 & 0,00 & 27,88 & 0,18 & 6,62 & 0,00 & 0,44 & 9,27 & 99,82 \\
\hline 15 & ZC-46/2-59- 1 & tuffite & 33,69 & 5,73 & 12,89 & 0,00 & 26,16 & 0,11 & 6,26 & 0,00 & 0,42 & 8,69 & 93,95 \\
\hline 16 & & & 32,94 & 5,71 & 12,99 & 0,00 & 26,86 & 0,17 & 5,99 & 0,00 & 0,28 & 8,47 & 93,41 \\
\hline 17 & & & 32,96 & 5,88 & 13,78 & 0,00 & 28,00 & 0,23 & 6,38 & 0,00 & 0,41 & 7,97 & 95,61 \\
\hline 18 & & & 34,20 & 5,23 & 13,58 & 0,00 & 25,93 & 0,16 & 6,27 & 0,02 & 0,41 & 7,88 & 93,68 \\
\hline 19 & & & 33,11 & 5,41 & 13,23 & 0,00 & 26,99 & 0,17 & 6,33 & 0,00 & 0,32 & 8,75 & 94,31 \\
\hline 20 & & & 33,63 & 5,66 & 13,28 & 0,00 & 25,92 & 0,09 & 6,48 & 0,01 & 0,45 & 8,89 & 94,41 \\
\hline 21 & & & 33,34 & 5,66 & 13,68 & 0,00 & 26,95 & 0,15 & 6,42 & 0,01 & 0,40 & 8,41 & 95,02 \\
\hline
\end{tabular}

X-ray spedrum andyysis (Mi đo Beam Comerainstrument), IMGRE Lobordary, theandyst I.M.Kulikova 2000.

they are volcanic glass replaced by shaly minerals and hematite aggregates, and in less extent rocks of oligophyric and plesiophyric structures are observed. Biotite phenocrysts content in schistose apovitreous matrix varies of single and occasional grains to $10-35 \%$ of rock volume. Apatite, zircon, ore mineral (magnetite), and feldspathoids occur in secondary or accessory amounts; they form idiomorphic inclusions of 0,005-0,1 $\mathrm{mm}$ size, occasional twins and aggregates with biotite, i.e. together with biotite they form paragenetic association of originally magmatic minerals. graphs [4] partly fall within the field of biotites from minettes, and partly they drift towards the field of higher iron content.

Apatite forms well cut crystals of prismatic, elongated/prismatic, less short-prismatic habit with hexahedral prism, dipyramide, and pinacoid habit development. Crystal size by the long axis varies from 0.15 to $0.4 \mathrm{~mm}$, the short axis is less than $0.05 \mathrm{~mm}$ (rarely up to $0.10 \mathrm{~mm}$ ) length. Crystals are transparent, colorless, with the finest non-defined dust-like inclusions; the higher content of these inclusions make crystals semitransparent and milk-white. Apatite is 
T dble2: Geochemiod proper ties of lampr ophyr es and vendion sedimentary r aces

(oxides - moss \%, dements - $g / t$ )

\begin{tabular}{|c|c|c|c|c|c|c|c|c|c|c|c|c|}
\hline $\mathrm{N}$ & 1 & 2 & 3 & 4 & 5 & 6 & 7 & 8 & 9 & 10 & 11 & 12 \\
\hline$n$ & 7 & $\overline{1}$ & 1 & 7 & $\overline{2}$ & 4 & 4 & 5 & 4 & & & 2 \\
\hline $\mathrm{SiO} 2$ & - & 40,73 & 42,35 & - & 44,11 & 42,59 & 59,12 & 61,80 & 72,56 & 41,23 & 55,99 & 66,60 \\
\hline $\mathrm{TiO}$ & - & 1,32 & 0,67 & - & 0,64 & 0,18 & 0,69 & 0,76 & 0,62 & 0,51 & 1,25 & 0,75 \\
\hline $\begin{array}{l}\mathrm{Al} 2 \mathrm{O} 3 \\
\mathrm{Fe} 2 \mathrm{O3}\end{array}$ & - & 28,20 & $\begin{array}{l}2 /, 29 \\
1185\end{array}$ & - & $\begin{array}{l}29,03 \\
283\end{array}$ & $\begin{array}{l}21,21 \\
14 ? 7\end{array}$ & $\begin{array}{l}15,42 \\
789\end{array}$ & $\begin{array}{l}14,14 \\
660\end{array}$ & $\begin{array}{l}12,10 \\
258\end{array}$ & 9,68 & 22,11 & 14,23 \\
\hline $\mathrm{F} \oplus \mathrm{O}$ & - & 0,30 & 0,27 & - & 3,55 & 0,14 & 0,40 & 0,32 & 0,71 & 0,41 & 207 & 235 \\
\hline $\mathrm{MnO}$ & - & $<0.01$ & 0,03 & - & 0,03 & 0,05 & 0,02 & 0,04 & 0,04 & 0,07 & 0,02 & 0,02 \\
\hline MgO & - & 1,54 & 1,25 & - & 2,38 & 2,57 & 1,98 & 2,28 & 1,66 & 1,75 & 1,35 & 2,29 \\
\hline $\mathrm{COO}$ & - & 0,57 & 1,16 & - & 0,87 & 0,81 & 0,70 & 0,93 & 0,60 & 11,06 & 0,84 & 0,68 \\
\hline $\mathrm{NoRO}$ & - & 0,24 & 0,07 & - & 0,28 & 0,06 & 0,68 & 0,74 & 1,14 & 0,53 & 0,55 & 1,01 \\
\hline$k 20$ & & 1,31 & 2,06 & - & 1,68 & 4,31 & 4,33 & 4,23 & 3,21 & 2,88 & 2,26 & 3,33 \\
\hline P205 & - & 0,18 & 0,20 & - & 0,19 & 0,03 & 0,05 & 0,09 & 0,08 & 7,12 & 0,27 & 0,10 \\
\hline$a$ & & 13,69 & 13,22 & - & 13,92 & 13,27 & 8,25 & 7,69 & 4,49 & 8,55 & 8,35 & 5,56 \\
\hline Totd & - & 99,94 & 100,42 & - & 99,49 & 99,55 & 99,53 & 99,63 & 99,74 & 99,33 & 100,30 & 100,01 \\
\hline $\mathrm{H} 2 \mathrm{O}$ & - & 3,22 & 4,02 & - & 3,39 & 7,28 & 4,42 & 4,31 & 1,78 & 3,18 & 1,89 & 2,09 \\
\hline $\mathrm{H} 2 \mathrm{O}+$ & - & 9,93 & 8,82 & - & 10,01 & 5,74 & 3,56 & 2,82 & 2,38 & 1,87 & 6,30 & 3,46 \\
\hline $\mathrm{CO} 2$ & 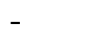 & 0,54 & 0,39 & - & 0,28 & 0,32 & 0,26 & 0,50 & 0,38 & 3,32 & $<0.20$ & 0,15 \\
\hline Stotd & & $<0.05$ & 0,08 & - & 0,06 & $<0.05$ & $<0.05$ & $<0.05$ & $<0.05$ & 0,06 & $<0.05$ & $<0.05$ \\
\hline $\mathrm{Li}$ & 199,0 & 459,3 & 188,3 & 122,3 & 250,85 & 29,56 & 28,36 & 29,76 & 49,80 & 27,9 & 131,1 & 45,47 \\
\hline $\mathrm{Be}$ & 4,71 & 5,76 & 3,12 & 3,05 & 3,36 & 3,16 & 3,33 & 3,07 & 1,32 & 3,00 & 2,26 & 1,71 \\
\hline Sc & $\begin{array}{l}11,8 \\
5275\end{array}$ & $\begin{array}{l}17,6 \\
6872\end{array}$ & $\begin{array}{l}10,4 \\
3652\end{array}$ & $\begin{array}{l}19,6 \\
210 k 8\end{array}$ & 14,0 & $\begin{array}{l}8,8 \\
872\end{array}$ & $\begin{array}{l}14,73 \\
3011\end{array}$ & $\begin{array}{l}13,68 \\
1008\end{array}$ & 10,07 & $\begin{array}{l}10,2 \\
28 k 8\end{array}$ & 13,2 & $\begin{array}{l}14,37 \\
4342\end{array}$ \\
\hline V & 627 & 313 & 50,4 & $\begin{array}{l}21000 \\
1705\end{array}$ & 3221 & 1038 & $\begin{array}{l}5441 \\
6432\end{array}$ & $\begin{array}{l}4290 \\
7110\end{array}$ & 6236 & $\begin{array}{l}2000 \\
705\end{array}$ & $\begin{array}{l}1201 \\
752\end{array}$ & $\begin{array}{l}4042 \\
7706\end{array}$ \\
\hline a & 36,0 & 6,1 & 27,1 & 137,6 & 6,62 & 0,12 & 56,76 & 72,15 & 71,07 & $\begin{array}{l}10,0 \\
58,02\end{array}$ & $\begin{array}{l}10,2 \\
41,68\end{array}$ & $\begin{array}{l}11,00 \\
71,39\end{array}$ \\
\hline Co & 5,1 & 4,6 & 4,5 & 15,5 & 11,64 & 6,15 & 10,70 & 10,47 & 11,06 & 7,37 & 10,68 & 15,15 \\
\hline $\mathrm{Ni}$ & 18,4 & 22,2 & 8,4 & 31,9 & 31,25 & 4,70 & 19,81 & 17,26 & 23,49 & 13,16 & 20,49 & 32,25 \\
\hline â & 5,2 & 7,6 & 11,0 & 29,9 & 667,56 & 8,95 & 15,02 & 12,63 & 12,01 & 9,52 & 537,12 & 31,35 \\
\hline $\mathrm{Zn}$ & 46,9 & 33,4 & 25,8 & 92,1 & 45,8 & 23,05 & 61,54 & 64,68 & 52,22 & 42,3 & 68,4 & 70,56 \\
\hline Ga & 14,6 & 25,9 & 16,2 & 21,9 & 18,2 & 25,48 & 24,06 & 22,49 & 16,96 & 18,3 & 20,3 & 20,25 \\
\hline $\mathrm{Rb}$ & 36,7 & 20,3 & 24,6 & 105,4 & 31,71 & 38,69 & 139,30 & 141,13 & 101,25 & 99,6 & 60,9 & 118,26 \\
\hline $\begin{array}{l}\text { Sr } \\
\text { Y }\end{array}$ & 73,3 & 87,4 & 89,6 & 95,5 & 81,43 & 114,43 & 111,02 & 107,61 & 87,01 & 240,4 & 67,2 & 83,62 \\
\hline $\mathrm{Zr}$ & 822,0 & 660,1 & $\begin{array}{l}50,9 \\
535,9\end{array}$ & $\begin{array}{l}82,4 \\
1122,1\end{array}$ & $\begin{array}{l}01,02 \\
443,86\end{array}$ & $\begin{array}{l}20,24 \\
220,71\end{array}$ & $\begin{array}{l}40,41 \\
263,54\end{array}$ & $\begin{array}{l}40,46 \\
296,13\end{array}$ & $\begin{array}{l}3 /, 16 \\
31134\end{array}$ & $\begin{array}{l}589,1 \\
195,3\end{array}$ & $\begin{array}{l}60,8 \\
9277\end{array}$ & $\begin{array}{l}38,15 \\
3655\end{array}$ \\
\hline $\mathrm{Nb}$ & 38,2 & 25,4 & 30,2 & 76,4 & 35,20 & 37,03 & 23,36 & 19,25 & 15,02 & 12,6 & 35,0 & 18,36 \\
\hline Mo & 1,34 & 1,54 & 0,82 & 0,69 & 0,18 & 3,37 & 0,82 & 0,84 & 0,22 & 2,06 & 0,65 & 0,21 \\
\hline $\mathrm{Cd}$ & 0,27 & - & 0,25 & 0,69 & - & - & - & - & 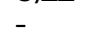 & & - & 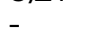 \\
\hline $\mathrm{Sb}$ & & - & 14,51 & 8,96 & - & - & - & & - & & - & - \\
\hline Cs & 2,18 & 1,63 & 1,54 & 4,22 & 1,56 & 3,35 & 6,68 & 5,97 & 3,52 & 3,79 & 1,90 & 4,03 \\
\hline $\mathrm{Ba}$ & 173,7 & 138,4 & 338,4 & 1036,7 & 307,24 & 245,79 & 438,02 & 402,13 & 327,57 & 471,0 & 497,0 & 333,17 \\
\hline La & 49,3 & 113,4 & 43,4 & 52,5 & 48,9 & 13,40 & 44,70 & 38,91 & 30,42 & 175,0 & 99,6 & 36,15 \\
\hline $\begin{array}{l}\mathrm{Ce} \\
\mathrm{Pr}\end{array}$ & 152,0 & 397,6 & 122,2 & $\begin{array}{l}153,9 \\
0\end{array}$ & 161,2 & $\begin{array}{l}50,84 \\
5\end{array}$ & 103,52 & 82,02 & 68,59 & 412,8 & 344,8 & 78,43 \\
\hline $\mathrm{No}$ & 65,7 & $\begin{array}{l}44,8 \\
167,8\end{array}$ & $\begin{array}{l}14,3 \\
55,1\end{array}$ & $\begin{array}{l}18,1 \\
71,5\end{array}$ & $\begin{array}{r}18,81 \\
76,86\end{array}$ & $\begin{array}{l}5,32 \\
21,11\end{array}$ & $\begin{array}{l}10,8 / \\
41,36\end{array}$ & $\begin{array}{l}8,48 \\
32,72\end{array}$ & $\begin{array}{l}1,35 \\
27,80\end{array}$ & $\begin{array}{l}55,49 \\
254,7\end{array}$ & $\begin{array}{l}33,19 \\
127,5\end{array}$ & $\begin{array}{l}8,92 \\
32,74\end{array}$ \\
\hline $\mathrm{Sm}$ & 12,65 & 30,88 & 9,24 & 14,82 & 14,46 & 4,47 & 7,89 & 6,41 & 5,51 & 78,54 & 24,90 & 6,41 \\
\hline Eu & 2,27 & 5,31 & 1,62 & 2,44 & 2,27 & 0,69 & 1,30 & 1,18 & 1,04 & 13,95 & 4,01 & 1,14 \\
\hline Go & 13,95 & 24,79 & 9,03 & 15,76 & 11,85 & 4,25 & 6,89 & 6,38 & 5,68 & 88,1 & 20,61 & 6,06 \\
\hline $\mathrm{Tb}$ & 2,76 & 3,54 & 1,46 & 2,44 & 2,01 & 0,70 & 1,08 & 1,02 & 0,92 & 11,75 & 2,7 & 0,94 \\
\hline Dy & 19,31 & 20,07 & 9,49 & 15,07 & 11,50 & 4,60 & 6,74 & 6,43 & 5,97 & 62,07 & 13,47 & 5,76 \\
\hline $\mathrm{Ho}$ & 4,34 & 3,79 & 1,87 & 2,94 & 2,43 & 1,00 & 1,38 & 1,36 & 1,27 & 11,34 & 2,14 & 1,22 \\
\hline Er & 11,18 & 10,14 & 5,34 & 8,12 & 6,97 & 3,07 & 4,21 & 3,90 & 3,48 & 26,55 & 5,64 & 3,73 \\
\hline $\operatorname{lm}_{y b}$ & 2,04 & $\begin{array}{l}1,30 \\
835\end{array}$ & $\begin{array}{l}0,85 \\
454\end{array}$ & $\begin{array}{l}1,08 \\
649\end{array}$ & $\begin{array}{l}1,04 \\
622\end{array}$ & $\begin{array}{l}0,48 \\
3,8\end{array}$ & $\begin{array}{l}0,66 \\
47\end{array}$ & $\begin{array}{l}0,60 \\
, 02\end{array}$ & $\begin{array}{l}0,51 \\
3,32\end{array}$ & $18 \cap 8$ & $\begin{array}{l}0,75 \\
105\end{array}$ & $\begin{array}{l}0,52 \\
3,57\end{array}$ \\
\hline $\mathrm{Lu}$ & 1,62 & 1,14 & 0,67 & 1,00 & 0,87 & 0,48 & 0,67 & 0,61 & 0,51 & 2 & 0,7 & 0,52 \\
\hline $\mathrm{Hf}$ & 324 & 26,9 & 15,0 & 25,4 & 16,12 & 8,60 & 7,51 & 7,80 & 7,92 & 5,3 & 22,68 & 9,09 \\
\hline Ta & 6,11 & 5,87 & 2,82 & 3,59 & 4,66 & 2,16 & 1,26 & 1,07 & 0,88 & 0,8 & 2,13 & 0,88 \\
\hline W & 1,58 & 1,78 & 0,92 & 2,43 & 0,83 & 0,8 & 1,00 & 1,23 & 1,07 & 2,45 & 1,08 & 0,81 \\
\hline $\mathrm{TI}$ & 0,31 & 0,36 & 0,12 & 0,48 & 0,39 & 0,08 & 0,79 & 0,86 & 0,65 & 0,61 & 0,44 & 0,59 \\
\hline $\mathrm{Pb}$ & 13,5 & 21,5 & 18,9 & 28,1 & 5,03 & 21,82 & 15,54 & 11,42 & 7,44 & 56,87 & 8,05 & 6,12 \\
\hline $\mathrm{Bi}$ & & & - & & & 0,04 & 0,05 & 0,11 & 0,10 & 1,2 & 0,06 & 0,06 \\
\hline Th & 61,4 & 61,0 & 48,9 & 32 & 59,8 & 27,03 & 16,46 & 13,16 & 9,62 & 9,3 & 36,10 & 11,77 \\
\hline 1 & 7,95 & 6,27 & 1,83 & 4,83 & 6,58 & 1,16 & 2,07 & 2,87 & 3,54 & 38,47 & 6,64 & 2,30 \\
\hline
\end{tabular}

Note 1,2 - qphyriclava(cover); 3- diggphyriclava(cover); 4 - plesi qphyriclava(vein); 5 - tuff, lithorystod astic, deurcosammitic, 6- sporadbphyricl ava(cover); 7 - redd sh-brown silty doy with vd coric cmaterid; 8 - dak brown silty doy; 9, 12 Vend an sil tstane; 10 - phospharites nodila, quatzeas, silty; 11 - lithoorystod ostictuffites; 12 - light geenish-gay Vend an siltstones; (-) - not ardilde. ICP-MS andysis ("PLASMA @D" instrument), IGEM RAS Ldbordory, the Andyst D.Z.Zhuralyov, 2000 
characterized by very simple composition with minimum content of REE; however, with stable Sradmixture $(0,11-0,15 \% \mathrm{SrO})$ and moderate admixture of LREE $\left(0,13-0,57 \% \mathrm{Ce}_{2} \mathrm{O}_{3}\right)$.

Zircon, as well as apatite, is of $-0,10 \mathrm{~mm}$ size, occasional grains are of $0,2-0,4 \mathrm{~mm}$ size along the long axis and the short axis is up to $0.05 \mathrm{~mm}$. Zircon is represented by elongated prismatic (to needle-like), prismatic, rare short-prismatic, well-cut crystals with dipyramidal ends. Zircon crystals are transparent, almost colorless, slightly tinged with yellow and pink. Some crystals are saturated with various (including melt) inclusions and are characterized by zonal structure underlining their magmatic nature. Elongated prismatic to needle-like, pointed zircon crystals occur usually in magmatic rocks crystallized under conditions of fast cooling that properly conforms to general geological setting and petrographic properties of the studies lamprophyre lavas. U-content in lamprophyric zircon of the sample ZC-14/3-51.8 is of $100-200 \mathrm{~g} / \mathrm{t}$ that is typical of zircons of non-kimberlite magmatic rocks, in particular, of sienites and carbonatites.

Magnetite was found as individual grains of black, flat octahedral crystals of $<0.1 \mathrm{~mm}$ size, quite often it is pseudomorphically altered by hematite (martite).

Hematite is represented by very small grains of irregular shape and $<0.1 \mathrm{~mm}$ size. Lustre is internsive, metallic; hematite is black, brownish-red when in powder.

Feldspathoids_occur as small (0.05-0.07 mm size), close to idiomorphic or irregular grains of potassic feldspar of $\mathrm{N}<\mathrm{N}$ k.b. and with strike joints, probably, as potassic feldspar grains. Occasional subidiomorphic grains of isotropic potassic (presumably) feldspar (?) of 0/03$0.065 \mathrm{~mm}$ size with two orthogonal jointing systems.

Tuffs and tuffites are of bluish-gray or greenish -gray color, of crystoclastic aleuropsammitic structure and indistinct undulatory / bedded texture, sometime with elements of gradational texture. Crystoclasts are represented by biotite packets (occasionally by laths) similar to biotite phenocrysts of effusive rocks in size, composition, and replacement type, and also by the same accessory minerals (apatite, zircon, feldspathoids, ore mineral) that are contained in lavas. Lithoclasts are usually replaced by quartzine aggregates. Tuffites of the anomaly ZG-46 are of unusually fresh habit proved by occurrence of unaltered biotite packets in aggregation with apatite and zircon and in occurrence of perfectly preserved lithoclasts diverse in structure: microfragments of scopria, various amygdaloidal lavas, and microdolerites.

Volcanic sedimentary rocks (tuff siltstones and tuff mudstones) are usually developed in lava and tuff sheets top - within the zone of gradual volcanic rocks replacement by sedimentary rocks. They are of reddishbrown color and differ from common sedimentary rocks of the area in occurrence of occasional fragments of lava material, primarily, of typical pseudomorphs of network structure in biotite pakets.

In general, in the respect of petrographical composition, the studied volcanic rocks are close to different structural and genetic derivatives of magma melts of calc- alkali lamprophyre of minette type.

\section{GEOCHEMISTRY}

All studied volcanic rocks have been highly altered in weathering crust conditions; therefore, their original chemical composition is significantly changed. Chemical composition of volcanic rocks is characterized by predominating development of two rock-forming components: $\mathrm{SiO}_{2}$ and $\mathrm{Al}_{2} \mathrm{O}_{3} . \mathrm{SiO}_{2}$ content is quite stable and low: $40,73-46,48 \%$ in rocks of lava type, ca $44 \%$ in tuffs that agrees with composition of ultrabasic or transitional to basites rocks. Very high content of $\mathrm{Al}_{2} \mathrm{O}_{3}(22,97-29,52 \%)$ can be explained mainly by its accumulation under weathering. Deposits are potassic $\left(\mathrm{K}_{2} \mathrm{O} / \mathrm{Na}_{2} \mathrm{O}>4\right)$, Ticontent in rocks is low to moderate $(0.16-1.32 \%$ of $\mathrm{TiO}_{2}$ ). Rocks are characterized by extremely low content of ultrabasic coherent trace elements $(\mathrm{Ni}, \mathrm{Co}$, $\mathrm{Cr}$ ), higher content of alkali $(\mathrm{K}, \mathrm{Rb}, \mathrm{Cs}$, and especially $\mathrm{Li}$ ), Ba and very high content of $\mathrm{Zr}, \mathrm{Hf}, \mathrm{Y}$, Th, REE (tabl. 2).

In general, macrocomponents and trace elements distribution does not contradict the assumption that the studied rocks are close to lamprophyres of minette type, and in $\mathrm{Zr}-\mathrm{Nb}$ relation they are even closer to lamproites. Lavas of different anomalies are slightly different in composition.

\section{ABSOLUTE AGE}

Determination of absolute age with the use of $\mathrm{U}-\mathrm{Pb}$ method of zircon dating was carried on by ARC National Key Center GEMOS, Sidney, Australia. Optimal dating of the studied volcanic rock crystallization is $570 \pm 8 \mathrm{Ma}$ that corresponds to Late Vendian and actually coincides with the Proterozoic/ Phanerozoic boundary.

\section{CONCLUSIONS}

Discovered volcanites of the new type make a chain of northeastern trend, parallel to the White Sea Entrance. Possibly, they are correlated with faults that are located parallel to fault system of the White Sea Entrance graben and transversal to Kola-Dvina Riphean paleorift system that could characterize them as "transform" faults and the associated alkaline aerial volcanism as rift-type volcanism.

These are first magmatic rocks of petrological type and age different from those of well-known Late Devonian explosion pipes and kimberlite sills, picrites, melilithites, and basalts. Potassic type of these volcanites and assumed relation with active rift transform faults could indicate that their magmatic chambers are of mantle nature that in its turn assumes possible occurrence of Late Vendian mantle melts and other bodies of the same age, including kimberlites, within the Winter Coast area. 


\section{REFERENCES}

1. Geological structure, mineralogical and petrological properties of kimberlites of Arkhangelsk Province (1991): Verichev E.M., Garanin V.K., Grib V.P., Kudryavtseva G.P.; High School Transactions, Geology, \#4, pp. 88-94.

2. Shirobokov V.N. (1997): Some specific features of the Winter Coast diamondiferous area structure; Subsoil Prospecting and Protection, pp. 21-25.
3. Erinchek Yu.M., Milshtein E.D. (1995): Riphean riftforming of the central East-European Platform; $\mathrm{SPb}$, VSEGEI.

4. 4. Mitchell R.H. (1995): Compositional variation of mica in kimberlites, orangeites, lamproites and lamprophires. Extended Abstr. 6 IKC, Russia> pp.390392.

Contact: Shchukin V.S., 163045 Arkhangelsk,

261, Lomonosov av., Russia, E-mail: aa@mail.sts.ru 